\title{
Cartesian Diver Studies on Respiration of Rat Bone Marrow Cells in the Presence of Erythropoietin and Anti-Erythropoietin
}

It is known that erythropoietin ( $\mathrm{ESF}$ ), elaborated by the kidney, stimulates heme synthesis in bone marrow cells in vitro ${ }^{1}$. Since respiration of bone marrow cells has been investigated by various methods ${ }^{2}$, the purpose of the present investigation was to measure respiratory activity of bone marrow cells in the presence of ESF and anti-ESF. In this respect, the Cartesian diver technique was of major interest because of the sensitivity of the system, the ability to use small quantities of cells, and the fact that $\mathrm{CO}_{2}$ may influence cellular metabolism ${ }^{3,4}$.

Methods. Bone marrow suspensions from male rats, Long-Evans strain, were used for all experiments. Sterile suspensions were obtained by flushing the bone marrow with $\mathrm{Ca}^{++}-\mathrm{Mg}^{++}$free salt solution, and then resuspending in Pucks or Hanks balanced salt solution. In experiments where ESF or anti-ESF was added, bone marrow from transfusion-induced plethoric rats was used ${ }^{5}$. The ESF was prepared from anemic human urine and had a specific activity of $4 \mathrm{U} / 0.25 \mathrm{ul}$. Anti-ESF was prepared according to the method of ScHooley and Garcia ${ }^{6}$. The Cartesian diver technique, which allows one to use micro samples of cells, has been described elsewhere ${ }^{3,7,8}$.

Results. Preliminary experiments using the microampulla diver technique of $Z_{\text {EUTHEN }}$, demonstrated that respiration of normal bone marrow cells is slightly lower in the presence of glucose as compared to without glucose (Crabtree effect). In Table I, all determinations were made with $200-300$ cells/diver and $0.1 N \mathrm{NaOH}$ as an absorbant at $37^{\circ} \mathrm{C}$. These results are not unusual in view of the numerous reports of reduced respiration of bone marrow and other elements in the presence of glucose ${ }^{9-12}$.

Table I. Ampulla diver determinations of bone marrow cells in Pucks salts with or without $0.018 \mathrm{M}$ glucose

\begin{tabular}{ll}
\hline$\Delta \mathrm{VO}_{2} / \mathrm{Cell} / \mathrm{h} \times 10^{-6} \mu \mathrm{l}$ & \\
\hline Cells without glucose & Cells with glucose \\
$0.97 \pm 0.17$ (4) & $0.73 \pm 0.15(4)$ \\
Controls (no cells) $=0.52,1.10 \times 10^{-5}$ & \\
\hline
\end{tabular}

Number of determinations in parenthesis. Average \pm S.D.

Table II. Respiration of bone marrow cells in Hanks balanced salt solution with or without ESF, anti-ESF and $10^{-3} M$ azide

\begin{tabular}{llll}
\hline $\begin{array}{l}\Delta \mathrm{VO}_{2} / \mathrm{Cell} / \mathrm{Hr} \times 10^{-6} \mu \mathrm{l} \\
\text { Cells } \\
4 \text { units ESF }\end{array}$ & $\begin{array}{c}\text { Cells }+ \text { ESF } \\
+ \text { anti-ESF }\end{array}$ & $\begin{array}{l}\text { Cells } \\
+10^{-3} M \text { Azide }\end{array}$ \\
\hline 1.25 & 0.46 & 0.73 & 0.28 \\
1.05 & 0.53 & 0.87 & 0.24 \\
1.04 & 0.61 & 1.15 & 0.41 \\
0.79 & 0.56 & 0.92 & \\
0.93 & 0.67 & 1.35 & \\
0.91 & 0.34 & 0.99 & \\
0.92 & 0.53 & 0.89 & \\
$0.99 \pm 0.14$ & 0.63 & 0.97 & \\
Controls (no cells) $=8.95,7.50,6.65 \times 10^{-4}$ & \\
\end{tabular}

Micro stoppered standard divers were used with a gas phase of $5 \%$ $\mathrm{CO}_{2}+95 \%$ air, and $400-2000$ cells/diver. Each figure represents an a verage. $4 \mathrm{~h}$ determination for 1 diver. Final total average calculated \pm S.D.
Studies on plethoric bone marrow cells (ESF responsive) demonstrated that cell respiration was lower in the presence of ESF, and that inhibition was overcome in the presence of anti-ESF $\left(0.54\right.$ vs $\left.0.99 \times 10^{-6}\right) \quad(0.98$ vs $0.99 \times 10^{-6}$ ) (Table II). All determinations were made with micro-standard stoppered divers, with a gas phase of $5 \%$ $\mathrm{CO}_{2}+95 \%$ air and absorbant seals of $\mathrm{NaHCO}_{3}{ }^{8}$. In divers without hormone, an equal amount of protein (albumin) was added to compensate for the added hormone in experimental divers.

Discussion. It is of interest to note that respiration in the presence of ESF was lower than normal control cells, and that this inhibition was overcome in the presence of anti-ESF. Inhibition by azide suggests that a functional cytochrome system exists. Apparently some of the bone marrow elements are responding to the hormone in such a way that the overall aerobic respiration of the cell population is decreased. Since a Crabtree effect may exist, it is possible that a increased anaerobic metabolism could account for the reduced respiration ${ }^{\mathbf{1 3 - 1 4}}$.

Résumé. L'étude de la respiration des cellules de la moelle des os du rat fut faite avec un plongeur Cartésien. Ces cellules, avec ou sans glucose, repirent à raison de $0,73 \pm 0,15$ et $0,97 \pm 0,17 \times 10^{-6} \mu 1 \mathrm{O}_{2} /$ cellule $/ \mathrm{h}$. Comparée aux mesures de contrôle, la respiration des cellules médullaires de rats pléthoriques est plus fabile en présence de ESF $\left(0,45\right.$ contre $0,99 \times 10^{-6} \mu 1 \mathrm{O}_{2} /$ cellule/h). Cette inhibition fut supprimée par la présence d'anti-ESF $(0,98$ contre $0,99 \times 10^{-6} \mu \mathrm{l} \mathrm{O} /$ cellule/h).

\section{J. D. Lutton ${ }^{15,16}$, E. D. Zanjani, M. J. Kopac and A. S. GORDON}

Department of Biology and

Laboratory of Experimental Hematology,

New York University,

Graduate School of Arts and Science,

New York (N.Y. 10003, USA), 14 December 1971.

1 S. B. Krantz, O. Gallien-Lartigue and E. Goldwasser, J. biol. Chem. 238, 4085 (1963).

2 R. M. Gesinski, J. H. Morrison and J. R. Tokpfer, J. appl. Physiol. 24, 751 (1968).

3 K. Linderstrøm-Lang, C. r. Trav. Lab. Carlsberg Ser. Chime. 24, 333 (1943).

4 B. S. Danes and J. Kieler, C. r. Trav. Lab. Carlsberg 31, 61 (1958).

5 J. F. Garcta and J. Schooley, Proc. Soc. exp. Biol. Med. 112, 712 (1963).

6 J. Schooley and J. F. Garcia, Blood, 25, 204 (1965).

7 E. J. Zeuthen, J. Embryol. exp. Morph. 7, 239 (1953).

8 J. D. Lutton and M. J. Kopac, Cancer Res. 31 (12), 1.564 (1971).

9 J. M. Goldinger, A. Lipton and E. S. G. Barron, J. biol. Chem. 171,801 (1947).

10 H. A. Krebs, Biochim. biophys. Acta 4, 249 (1950).

11 R. Oren, A. E. Farnham, K, Salto, E. Milofsky and M. KarnovSkY, J. biophys. biochem. Cytol. C 17, 487 (1963).

12 T. C. Detwiler and R. V. Zivkovic, Biochim. biophys. Acta 197, $117(1970)$.

13 H. GrossFeld, Endocrinology 65, 777 (1959).

14 J. T. Dingle, J. A. Lucy and H. B. Feld, Biochem. J. 79, 497 (1961).

15 Present address: Department of Cell Biology, New York University School of Medicine, 550 1st Ave., New York (N.Y. 10016, USA).

16 This research was supported by funds from a Damon Runyon Cancer Research Training Grant and the US Public Health Service. The senior author was a Damon Runyon Post-Doctoral Trainee. 